\title{
Institute of Optometrists of N.S.W.
}

has more than paid its way for the first time.

Ladies and Gentlemen,-

Having commenced a New Year in the history of this Institute, it will be well for us to give most careful consideration to the Ways and Means of continuing and holding our position as the educational Optometrical body in this State, at least until such time as the Govemment shall see fit to bring in Legislation to educate and control the profession.

The Institute has made rapid progress during the last few years, and we can look back with gratitude to those older members who fought for years to pat the Institute on a firm footing. The encouragement they got from the trade generally was very small, and the opitrion of the main body of Opticians was that the Institute would never justify its existence. Many of those old members lost heart and dropped out of active membership, but the few who stuck to the guns laid a fonndation which every member to-day chould take pride in strengthening and building up a structure which will live through the annals of Optometry in this State.

The Institute has becn most fortunate in securing a number of members who have studied and secured honours in the world's best Optical educational Institntions abroad, bringing the latest methods of Optometrical instruction with them, combined with the happy knack of being able to impart their knowledge to others. These gentlemen have worked unceasingly to put our educational scheme on a firm footing, and it is up to the members of the Institute to devise means to equip them with the necessary apparatus to crry out their task.

Up to four or five years ago tur expenses were comparatively small, and we were able to get together a substantial sum of money, which was plaeed in the reserve account in the Savings Bank, but with the advent of our present educational scheme and Joumal, together with the general increases in cost of carrying on, the reserve gradually disappeared, and we find it necessary under existing circumstances to keep our instructors short of apparatus, etc, which would materially assist them in the Practical. Instruction of their Students.

The work of the past year has been res markably good, especially eonsidering the diffeulties onder. which we have had to work as regards finance.

The Journal has been most ably edited and managed, and has made many friends outside the Institute, and I am very pleased to say

Clinics have been held monthly, which have proved most popular to the members, and classes for the instruction of Students intending to take the Institute's examinations have been inaugurated under the auspices of the Institute. Two of our members were sent to Adclaide as delegates to the A.O.A. Conference, and it will be necessary to send delcgates to Queensland this year. It is hoped to form a Permanent Publie Clinic in one or more of the poorer suburbs at no distant date if the necessary funds, can be found, when the Students would have an exceptional opportunity of gaining practical experience under expert supervision, $z ;$ : - The Institute has undertaken a guarantee to the amount of $£_{30}$ in the event of Professor Woll visiting N.S.W. during the year. This guarantee is to. cover the expenses of Professor Woll during his stay here, and we expect to raise this amount by the sale of tickets for the course of Lectures to be delivered by Professor 'Woll.

The visit of Professor Woll depends upon the other States giving a similar undertaking, and we hope to have some definite announce. ment very shortly:

- The visit of such an eminent Optometrist and Lecturer should present a unique opportunity to all sections of the Profession, and it is to he hoped that the enthusiasm created by the Lectures will induce other eminent Optical Scientists to visit us. 5 . $\ldots$ m?

A careful perusal of our Secretary's and Treasurer's reports for the past year will convince members that a remarkable lot of work has been done for the monies expended, at the same time showing impossibility of extending our services undcr present financial conditions.

When we eome to consider the tremendous amount of work which many of our members do for the benefit of the Institute, and the hours spent in study, writing, lectures, etc. hours which most of us spend in recreation of some form or other, we should be impressed with the recessity of giving them the means of demonstrating their work in a practical and pleasurable manner, at tha same time adding to our appreciation of their efforts.

From my remarks you will see that if the Tnstitute is to go ahead, it is absolutely essential that some means must be found to materially augment the Finances, and in any discussion which may arise on this subject, as on any other, I shall be glitd to hear suggestions from all members. 